\title{
7
}

\section{MUSEOLOGICAL ORGANISATIONS IN BRAZIL: BETWEEN DOORS AND GRIDS}

\author{
Wescley Xavier, Diana Castro, and Vanessa Brulon
}

In 2016, Globo.com, the main Brazilian news portal, published a study conducted by the São Paulo City Council, revealing that more than $70 \%$ of the residents of the biggest city in Brazil had never attended an art exhibition or theatrical play. Two years later, the Communication Science News Agency of the University of Buenos Aires described how the Argentinian government shut down the dance company Ballet Nacional de Danzas, which had performed in several cities where residents had never seen a dance performance before. These cases exemplify the elitist character of culture in Brazil and Latin America, where access to the production and consumption of culture is associated with economic power and formal education, both of which enable an understanding and appreciation of artisticcultural elaborations. Indeed, museums are not well-visited even when admission fees are very low, since a significant part of the population feels that they do not have the necessary knowledge to engage in such experiences (Goulding, 2013).

However, museums can be a locus of emancipation when public access is improved (Castro, 2013, 2016). Our perspective is based on the notion of museums' educational purpose (ICOM, 2015) and Alderoqui and Pedersoli's (2011) application of John Dewey's experimental pedagogy of learning and knowledge construction in the museum. We use Paulo Freire's perspective on the contributions from Dewey (and others), thereby prioritising the critical or political aspects of education and the goal of human emancipation. Alderoqui and Pedersoli (2011, p. 65) discuss how museums specifically offer visitors interactions, and that the difference between collections-based and experimental museums is that the latter often have well-defined pedagogical goals. However, the role of the experimental museum as a locus of emancipation, i.e., a museum that allows for experimentation that goes beyond the exhibition, needs deeper investigation.

Space and material features shape human actions, reactions and social relations (Dale, 2005; Carlile et al., 2013; Orlikowski, 2007). Thus, a museum's architecture 
and physical features can prompt social relations. As we discuss, the notion of 'boundary zones' (cf. Castro, 2016) challenges the idea that museums promote emancipation only through their exhibitions or activities. Boundary zones arise when the relationships between people create a social locus: a form of parallel spacetime in which meaningful experiences can take place for the individual and ultimately, society (Castro, 2016). They can appear in the queue to an exhibition, at cafés, in souvenir shops or other spaces suitable for talking or contemplating; they do not necessarily coincide with museum spaces. In the following, we refer to these permeable spaces, rather than specifically to museums and their material or immaterial holdings. We claim that human emancipation is nurtured when museums facilitate experimental experiences in boundary zones, and our case studies document this claim.

We pose three key questions: why are Brazilian museums still almost exclusive to the upper classes? Why do museums not attract the general public, even when they are free of charge? Are experimental museological experiences alternatives to traditional, passive museum experiences because they activate audiences, thereby promoting emancipation? Based on three Brazilian museum cases (two in Ouro Preto and one in Rio de Janeiro), we answer these questions by discussing processes of estrangement or familiarity between individuals and museums, as well as how these relationships are affected by the spatial dynamics of the museums in question. Finally, we explore the opportunities for emancipation from the perspective of how people experience museums in the boundary zones.

Brazilian museums are shaped by contradictions. They are places of cultural reinforcement because they function as mechanisms of distinction, legitimacy and maintenance of consensus and appropriation of the city. Conversely, museums can raise awareness about the presence of those contradictions in public cultural spaces and everyday life and illuminate how experimental experiences can mediate this cultural alienation process. The notion of experimental experience does not refer exclusively to experiences that are deliberately designed as experimental, but also to non-planned experimental experiences that take place within boundary zones.

\section{Culture as a mechanism of distinction}

The relationship between culture and social structures can be understood through Pierre Bourdieu's theoretical framework in which social relations are established in fields that are configured as networks of objective relationships between positions (Bourdieu \& Wacquant, 2012). To climb positions in the field, agents seek to accumulate power resources, or 'types of capital' (Bourdieu, 2011). Different types of capital can change their relative value according to the game in question (Bourdieu \& Wacquant, 2012). Certain types of capital are regarded as paramount and, therefore, are present in several fields (Sallaz \& Zavisca, 2007).

Here, we emphasise cultural capital: a set of intellectual qualifications, e.g., knowledge or information, that can be transmitted by family or school institutions (Thiry-Cherques, 2006). Because the dominant classes generally have a higher 
level of education, diplomas and degrees are associated with the bourgeois way of existence (Bourdieu, 2011). For someone to become part of the universe of legitimate culture, i.e., the universe of culture elements recognised by all agents, a bourgeois background or existence becomes necessary (Bourdieu, 2011). Thus, Bourdieu understands culture as a mechanism for distinction between classes. What distinguishes the different classes is the disposition demanded by the legitimate consumption of legitimate things, the aptitude to make a specifically aesthetic point of view on objects already constituted aesthetically - thus getting admiration from peers - and the even rarer capacity to constitute aesthetically what is ordinary (Bourdieu, 2011).

Although schools themselves reinforce the distinctive character of culture in the view of Bourdieu, Vieira and Vieira (2004) argue that education and culture can also challenge cultural distinction by nurturing a more inclusive development of individuals and society. Institutions that promote culture - particularly museums can promote development through civic consciousness and social inclusion (Canclini, 2009; Castro, 2016; Vergara, 2008). However, the social performance of museums is often criticised for serving market interests (Bruno, 2002), and museums may reinforce class divisions because their configuration, aesthetic character and degree of formalism repel those without cultural capital.

Education for emancipation, following the pedagogy of Freire (2001), generates a transforming action for freedom (Freire, 2007) and aims to overcome what Bourdieu calls the differentiating character of culture. For Freire, emancipation is built by education in a humane, dialectical and love-mediated process. Love in this perspective includes an individual disposition to respecting differences, listening, engaging in dialogue, aiming to 'be a better person' and changing the world. Human emancipation is a revolutionary act because it must change the way we perceive ourselves in the world (to a more critical and realistic view) and start new actions to make the world a better place, which means a fairer and more humane environment.

In Freire's view, the mission of underdeveloped countries towards their people is 'to overcome the limiting situation of being dependent societies and become beings-for-themselves' (2001, p. 73). Furthermore, Freire compares underdevelopment to maintaining a culture of silence that supports the structure of oppression. Breaking this silence can be an emancipatory function of museums, especially experimental museums, as they can provoke what Freire calls 'utopia,' i.e., the glimpse of a better world as a possibility and a value to be attained.

\section{Shaping museum spaces}

Culture can be understood as a conflictual spatial force. It is a powerful mechanism of city control, defining whether someone belongs in a given space by operationalising images and memories. As noted, despite their free admission programmes, the aesthetics of Brazilian museums discourage members of lower social classes from visiting. Moreover, the institutionalisation of culture reinforces its 
potential of 'constructing social relation identities in a multidimensional culture of everyday life' (Rectanus, 2002, p. 5).

The relationship between tangible and intangible cultural heritage directly creates exclusion zones where the aesthetics and functionalities of the building determine symbolically who are insiders or outsiders, for instance when a building and its surroundings are used as a reference for urban redesign that aims to preserve local history and heritage (Zukin, 2010). To counter these spatial exclusion mechanisms, museum professionals recognise the importance of transforming museums into more inclusive spaces by focusing on physical features such as architecture and spatial forms and their capacity to create meaning (Macleod, 2005). Simon (2010), Pruulmann-Vengerfeldt and Aljas (2011) and others have recently discussed how the 'participatory museum' institutionalises citizen participation along similar lines. Thus, museums have recently undergone severe reshaping, with massive investments in infrastructure (Macleod et al., 2012). Indeed, architecture has become a critical factor in engaging people physically, symbolically, functionally and experientially (Rectanus, 2006). Museum architecture can create a distinctive sense of local space, promoting stronger ties with communities, because it involves people in creating new forms of locality and ownership (Rectanus, 2006).

The concept of boundary zones is based on Freire's idea of human emancipation. Castro (2013) synthesised Freire's pedagogy by adapting it to museums and dividing it into four moments that take place dialectically and procedurally within individuals and in society. These moments are simultaneous and mediated by love. They are: (i) 'the unveiling of knowledge about himself [sic] and his reality through exhibitions and research' [which can happen in the museum]; (ii) 'the critique of the unveiled knowledge' [which happens to the individual living in society]; (iii) 'the transformation of the object into a subject or praxis' [which happens to the individual living in society]; (iv) 'the exhibition of the denunciation or announcement of a better world' [which can happen in the museum] (Castro, 2013, p. 199; comments added).

Boundary zones only exist as long as they are not institutionalised or modelled by the organisation; thus, they serve purposes that are beyond the control of the museum. They only occur in museums that welcome a diversity of audiences and objects, and present inclusive exhibitions that become free spaces for socialising. Boundary zones can result from the stimulus of museum exhibitions and content, empty spaces and the interaction between individuals there. Human emancipation, according to this perspective, can be fostered in museums. However, it depends on what happens to individuals and their relationships and communications within society, where love has a central place as fostered through dialogue. Therefore, emancipation is the action that surpasses awareness, translating into a transformative action that completes critical thinking in favour of a new social reality (Castro, 2016). 


\section{Methodology}

The analysis we present here is based on a multiple-case study focussing on crossdata synthesis. Cases were selected according to the predictability of results, which may be similar or inverse (Yin, 2009). We selected three Brazilian museums located in two important touristic cities. From Rio de Janeiro, the analysed case was the Rio de Janeiro Museum of Art (MAR); from Ouro Preto, we analysed the Casa dos Contos Museum and the Inconfidência Museum.

Data were collected and analysed using a mix of quantitative and qualitative methods. We used descriptive statistics to describe the results of a survey with visitors $(N=180$ in Rio de Janeiro and $N=74$ in Ouro Preto) in which boundary zones were explored in order to understand how museums strengthen human emancipation. Then, we carried out interviews and participant observations. The interviewed subjects were selected according to data saturation. In Ouro Preto we carried out 28 interviews and in Rio de Janeiro, 41. These interviews were carried out with the local population, visitors and representatives of organisations (museums, the city council and others). The interviews were analysed using categorial analysis, in which interview content is organised by pre-existing theoretical categories and those emerging from the analysis.

Rio de Janeiro is the second-largest city in Brazil and the country's most important tourist destination. It receives approximately 8 million tourists each year, including 1.3 million foreigners. Despite its cultural relevance, the principal tourist attractions are natural; museum directors in Rio de Janeiro lament that museums are only visited when it rains in the city (Castro, 2016). The MAR was inaugurated in 2013 as part of a project for the revitalisation of the Rio de Janeiro harbour area. It promotes the history and culture of the city through permanent and temporary exhibitions and cultural events.

Ouro Preto is a small town and stands out for its historical and cultural tourism. The city has been declared a UNESCO World Heritage Site, and it receives an average of 500,000 tourists every year who visit to enjoy the city museums and churches and to stroll through important historical sites. The Casa dos Contos preserves and promotes the history of the gold cycle, ${ }^{1}$ as well as national art and culture. Housed in a historic building, the museum was founded in 1973. The Inconfidência Museum, inaugurated in 1944, preserves and displays aspects of the Minas Gerais Conspiracy ${ }^{2}$ by relating it to the political, social and artistic scene of the city of Ouro Preto in the eighteenth and nineteenth centuries.

\section{Museums as axes of cultural segregation}

The cases demonstrate how cultural spaces play a key role in the process of cultural differentiation. Our interviews suggest that residents are not able to grasp how the exhibitions represent their own history. The production of the exhibitions seems to be a crucial element of this shortcoming, because the feeling of estrangement is triggered when residents realise that the exhibitions are made for, and offered to, 
tourists. This is true also of several festivals held in the city, particularly the local film festival held in Ouro Preto's main square. According to the locals, the festival is made 'for the sake of appearance,' because its programme does not reach the peripheral neighbourhoods. Local audiences often feel uncomfortable in the town centre, as they find its entire structure to be designed for tourists:

[As for] that film festival ... Imagine if you chose five neighbourhoods in Ouro Preto and had the festival reach those places too, [if you] took it to the neighbourhoods, away [from the city centre], you know? There was a jazz festival, but it was only held in the city centre. Take it to the communities! Let's teach people what jazz is. Take it to the community, have the community get involved with things. (R9)

They [residents] feel that things here are made to serve external interests, especially tourism. For instance, tourists are treated well, and many events are targeted at tourists. But most young people here feel neglected, abandoned. They don't feel that things are made for them, they don't see it that way. (R19)

The aesthetics of the local film festival have a degree of formalism that residents cannot access. Therefore, locals perceive the museums as extensions of the cultural offers targeted at tourists. Conversely, confronting local residents' sense of estrangement could prompt a sense of belonging to the cultural spaces and the historical centre of Ouro Preto. In addition to breaking through the symbolic and concrete barriers of museum spaces, it is also necessary to break the detachment between museums and audiences, the rest of society, and the ordinary life of individuals (Hanquinet \& Savage, 2012). The connection between art and what is real can be seen here as a starting and finishing point, and an unbreakable link between the artist and the beholder.

An apparently paradoxical detail shown by our data is the absence of places for visitors. Our data shows that the beaches in Rio de Janeiro compete for visitors from the museums. Furthermore, in MAR, where $78 \%$ of surveyed visitors lived in Rio de Janeiro city, we noted that $42 \%$ came from wealthier neighbourhoods, against $5 \%$ of visitors who came from the neighbourhoods surrounding the museum. The absence of visitors from the surrounding areas, which is compounded by the high degree of social inequality in Brazil, explain why locals fail to identify with or altogether relate to the museum content, as illustrated in the following utterance from an Ouro Preto resident: 'Residents have little interest in getting to know Ouro Preto. This is a fact, it's true. If you say, "Let's go to the museum on Sunday!" they won't go! They won't go because there is a lack of interest' (R7).

Our results indicate that an excess of content (in the form of objects) may be more detrimental to learning and human emancipation than the ways this content is displayed. This study emphasises the importance of creating empty spaces inside 
and around the museum, so visitors have enough time to reflect on the content displayed in the exhibitions. It is important to have a pleasant and adequately furnished place to pause, think and connect. In contrast to MAR, Ouro Preto museums do not have these pleasant spaces, such as cafés or squares, but only exhibition rooms.

When the teacher gets to the museum with a group of students to pay a simple visit, they behave like students who are visiting any given place. It's like a walk or a game. For some of them, the visit is somewhat significant, but for most, it's just a [mere] walk (R1).

So, this kind of relation [between residents and museums] does not exist. Despite schools' engagement, stimulating museum education projects in the last five years... Because I do not value such things that I do not know its meaning. So, I have to understand downtown places. I have to recognise the relevance of the Inconfidência Museum, why the Tiradentes statue is inside, how everything has been formed. Otherwise, I will walk through downtown staring at such places as beautiful buildings, but not being part of it. (R8)

Museum education projects may play a role in bringing the Ouro Preto local audiences and museums closer together. We refer specifically to how history is narrated, reconstituted by the 'winners' and passed on to the 'losers.' This phenomenon can be characterised as the vertical transmission of knowledge, where something that is known by someone is taught to those who know nothing. This is the task of museum curators, as they seek to stimulate responses and encounters between the public and the artworks. They must also invoke the political and social content in these artworks (e.g., painting, sculpture, audio-visual displays), which is, in turn, activated by emotional components, similar to how contemporary artists have so skilfully done (Franklin \& Papastergiadis, 2017; Smith, 2009).

\section{Turn the table? The boundary zones as alternatives}

In Ouro Preto, the key explanation for the museums' low rates of attendance by locals seems to be their historical detachment from cultural spaces. Local residents' low attendance rate is not caused just by lack of interest in the exhibitions, it also stems from a sense of estrangement from the spaces in the historic centre, which, in the eyes of the residents, are designed for tourists only:

I think that the people of Ouro Preto don't have a sense of belonging to the historic centre, or to this city which is a heritage site. The city centre is a commercial centre. (R1) 
[Most] people living on the outskirts have never visited a museum, there are people from Ouro Preto who have never ... They don't feel they belong in there. Many think that Ouro Preto is a city for tourists, that is, for tourist exploration and nothing else. There's really no sense of belonging, the city needs to work hard [to achieve that]. (R17)

This means that only tourists are able to benefit from the hypothetical transformation or emancipation allowed by museums. If locals do not visit their museums, they cannot interact, experience or construct a better place or way of being in the world. As for the MAR, two local women lamented the lack of human warmth in the museum, while another visitor claimed to feel lost in the exhibitions. Indeed, many locals refer to the museum as strange, distant and cold, or as an inaccessible place that few people can identify with:

There are many things displayed in the exhibitions, but there's little information [targeted at] those who do not understand [the subject]. It is as if it didn't arouse any interest at all. It's like sitting with a child with a storybook and lots of pictures. The child will browse it, but only when they have subtitles, right? They'll want to know, the clothes [the characters are wearing], whatever. Teachers are used to doing this, [they'll ask:] 'Are you paying attention to what is going on?' Why? [Because] it makes them want to learn (...) The way it is now, it's more like visiting an amusement park than a museum. It's not because it doesn't arouse curiosity, I think people are ashamed, maybe if they [the museums] were more disseminated as normal places to be visited... The membership card is not well-publicised, so it gives you access, but those who don't read it. ... (R14)

Some respondents point out that they only visit museums that are free of charge. Furthermore, they argue that museums are perceived by a significant part of Brazilian society as special, differentiated spaces, where the poor or those with less cultural capital are ashamed to go. Another problem reported by Rio de Janeiro locals is the difficulty of getting to the museum in terms of travel time and distance, but also the precariousness and cost of public transport. Some of the interviewed visitors were from neighbouring cities, the so-called Baixada Fluminense, a zone that has an inferior infrastructure and offers few cultural options. Thus, residents of these regions are required to travel to the upper-class neighbourhoods of the city if they are to visit museums:

No, it's not usual [to visit the museum]. Only when there's really ... It's about once every two years. Perhaps the attendance will increase, the problem is the structure. This is really good, but it is very difficult to get to the museum in Rio de Janeiro, [there is the issue of] parking. ... (R31) 
Thus, compared to other leisure spaces, museums seem difficult to access. As a reference, we estimated that for a family living in Nova Iguaçu (a city in the Baixada Fluminense that has no museums at all) it would take three hours by bus to go to the museum and come back, and they would have to change buses at least twice - an expensive and tiring journey.

We also investigated the museums' capabilities to engage local audiences. The Rio de Janeiro museum seems to have established a dialogue with the city, by organising programmes to introduce locals to museum spaces, showing exhibitions by local artists and addressing themes related to the surrounding community. We came across several cases where the museum was politically engaged through its curatorship. In one of them, the museum invited an artist to create an exhibition on a subject that was worrying the residents of a neighbouring slum, who were being evicted from their houses for a redevelopment project. The artist's work was made from the rubble and debris of the houses and he donated it to the museum as a piece of art so that the city hall had to incorporate it into its collection. It was a strong political act because the museum was not designed to have an art collection, only to host exhibitions. However, the act attracted attention because the rubble was left in the middle of the street, which created a social problem caused by the city hall. In another case, an artist created a portrait on the museum's wall of a resident who had been removed from his home because of a revitalisation project, forcing his presence through memory and art.

In contrast, the Ouro Preto museums are configured as tourist spaces. Interactive exhibitions seem to have a limited ability to bring the local population closer to its own history. Members of the local population only seem to recognise themselves in those spaces when they have been exposed to information and discussions about the content of the exhibitions:

When you take an ordinary person into a space that is listed as a heritage site, or to museums, and try to show that person that they belong there, that it's all their history, not a monument built for tourists [...] When they get into one of these places, having participated in the debate about what these places represent to them, there's a noticeable change in behaviour. That is, they come to identify with that and see themselves in that place, in that very place they're visiting. (R23)

The vast majority of visitors (95\% of our informants) at the Ouro Preto museums visited in groups. While $70 \%$ reported to have talked to someone about the museum collection and content, these conversations were held only with acquaintances, never with the museum staff or other visitors. Furthermore, the visitors of the Ouro Preto museums are rarely native to Ouro Preto; this leads to a detachment from the content of the exhibitions caused by a lack of identification. Finally, as the visitors only speak with their acquaintances, the museum experience does not necessarily affect their connection with the local culture and community, nor between the museum and the city. Among all our informants, $84 \%$ stated that 
they did not have suggestions for improvement, nor did they engage in interaction; this underscores the absence of dialogue, and the resulting missed opportunity for transformation of reality in these museums.

When the visitors were asked about their reason for visiting the museum, the second-most cited reason was 'to accompany someone,' followed by their 'interest in the city of Ouro Preto.' These answers lead us to conclude that Castro's (2016) emancipation categories, dialogue and transformation of reality, were not taking place. According to Freire, such dialogue must happen through different ideas that come into contact in a dialectic way. In the absence of a contradiction or antithesis, dialogues cannot properly occur. In other words, if visitors only engage in conversations with acquaintances, this presents no opportunity for human emancipation. We hypothesise that experimental exhibitions, designed to prompt interactions with strangers, can contribute to emancipation or at least, greater awareness of reality.

During their visit, a significant proportion of respondents $(84 \%$ of our informants) stated that they did not wish to make any suggestions or interventions. Among those who said they did, some mentioned their desire to obtain more information about the artists or the artworks on display. This supports the idea that the oppressed hosts the oppressor inside themself, an idea which assumes an unilinear relation of cultural transmission by the museum as a given (the 'culture of silence,' Freire 2011). The silence appears here as a voice that is silent through the oppressed acceptance and host of the oppressor's culture. Notably, we (and Freire) are speaking from the perspective of a very unequal society, which contains within itself many different cultural, social, educational, economical and residential levels of access. This goes against the principles of praxis and socialisation. Perhaps the respondents in question believe they have little to say or contribute when, in fact, their feelings merely reflect the introjection of a dominant, oppressive and hegemonic thinking in their minds that lays the foundations of the culture of silence. Perhaps the data denotes a tautological experience that returns to itself. Or the results may indicate a form of postmodern hedonism, taking pleasure in something that is regarded as important, or communicating to friends and acquaintances that what is supposed to be done (i.e., consumption of culture) has indeed been done. This form of hedonism can be fulfilled, for instance, by visiting a historic city or one of its museums. Again, we reach the same result: the act of going somewhere else to arrive at the same place, with the same convictions, because no dialogue with the local audience or the city has been established.

Another aspect that may affect the lack of reciprocity between visitors and museums is the lack of potential boundary zones such as public resting areas, enjoyment spaces or food courts in the museums. Indeed, the physical structure of the Ouro Preto museums consists exclusively of exhibition halls. Notably, visitors who registered as users on the website TripAdvisor reported that one hour is sufficient time to visit these museums without rushing. In other words, there is evidence that visitors adopt the role of flâneurs (Urry, 1991) without contemplating, discovering or appropriating reality. 
In contrast, the Rio Art Museum has a large, fenced open space, as well as a café, a restaurant, a souvenir shop, a terrace, meeting rooms and auditoriums. These facilities may become spaces for experimentation because visitors can interact and talk about what they have experienced in the exhibitions. These potential boundary zones were only present in the Rio de Janeiro museum, where they offered ways to experience museums, other than through their content, that are important for the emancipatory process.

We found evidence of emancipatory processes, such as changed perceptions of reality, of self-esteem, and of justice, in interviews with visitors following their visit. We probed those visitors who responded positively, inquiring whether the change was caused by museum content (mainly art objects) or other things or events. Some visitors mentioned seeing homeless people in front of or inside the museum, asking for money (or visiting); others discussed how the contrast between the new, beautiful and rich buildings and the surrounding favelas made them think about emancipation-related themes. Further, some visitors mentioned how expensive the visit was to them and how their peers cannot come into the museum. Finally, some thought that 'it is not up to them' to reflect about the shortcomings in their society.

One woman described how she misses out when she doesn't go to museums (or cultural places), as illustrated here: 'I stay a slave to television, seeing boring movies, some soap operas that don't add (culturally) anything, just showing violence, people cheating on each other. What does it add? Nothing' (R 24). When prompted about this effect of museum visits, she described how every time she goes into a museum or to a cinema, something changes within her; not just because of the content, but also the experience: 'Anywhere (cultural) thoughts change, expand. We don't realise, but when we go out we realise that we are not the same' (R. 24).

At MAR, we noticed that the visits awakened or increased the feeling of wanting to learn with the different cultures for $82 \%$ of visitors. After the visit, $76 \%$ of the visitors stated that they started to think more about cultures or groups that they knew little or nothing about. This suggests that the museum played a role in arousing curiosity about diversity, for instance:

$\begin{array}{ll}\text { Interviewer } & \begin{array}{r}\text { Did the visit to the museum increase or make you more aware of how } \\ \text { critically you perceive the society in which you live? }\end{array} \\ \text { R 25 } & \text { Yes, because the exhibition does it. } \\ \text { Interviewer } & \text { Was it related to the exhibition? } \\ \text { R 26 } & \text { Yes! } \\ \text { R 25 } & \text { For sure, the one with pictures, then! } \\ \text { Interviewer } & \text { Was it also related to the tour, to the whole context? } \\ \text { R 25 } & \text { Yes. } \\ \text { R 26 } & \text { There's no way why ... not having it, because, what happens? You're } \\ & \text { talking about one, about a city, so it's in that context. }\end{array}$


The two respondents went on to talk about the landscape they saw from the rooftop of the museum, which included a new, beautiful building and another museum, but also slum areas and poor neighbourhoods. Further, they talked about how they felt discriminated against when they discussed visiting museums and other cultural places, because the nearby city they live in is known as being 'not so well developed':

R 25 Discrimination ... discrimination is oppression!

R 26 It is a very complex context, you know.

R 25 I, I speak directly, about oppression, discrimination, once again I speak, for the neighbourhood, for the city I live in.

R 25 So sometimes, clearly, the person speaks like this, you don't live there, you don't have the physique, you don't have the intellect ... I mean, this is discrimination because a suburban neighbourhood or a city that is not so well, unfortunately, developed financially, cannot have intelligent people? In the 21st century, we live. So, when you say: hey, you live in São Gonçalo, but it's not possible, you speak well ...

This belief that the museum 'is not for everyone' seems socially accepted in Brazil and permeates interviews with visitors, staff and managers. Even though this belief is generated and reinforced in social interactions outside museums, it is also represented in exhibitions, as exemplified in the following exchange:

Interviewer $\begin{aligned} & \text { Did the visit to the museum change the way you see the city of Rio de } \\ & \text { Janeiro? } \\ & \text { Yes, a lot. } \\ & \text { R27 } \\ & \text { Interviewer } \\ & \text { R27 id have to do with the exhibition? } \\ & \text { It was. And with the ride. Especially with the terrace. That part over there. } \\ & \text { There was a person there explaining, it was really cool, then she even } \\ & \text { criticises the vehicle, not in the sense of being good or bad, but it is a } \\ & \text { criticism, to think about, right. } \\ & \text { People from the favela. } \\ & \text { R28 } \\ & \text { R27 } \\ & \text { think it's really cool what you did here, so it's the beginning that you } \\ & \text { have an overview, you have the mundane, and there's a story, right after } \\ & \text { that. I know that these exhibitions will change over time, but today's } \\ & \text { one was really cool. }\end{aligned}$

In interviews, managers, curators and staff at the MAR discussed the changes that occurred in some visitors when homeless people visited the museum. Historically, museums welcomed homeless people, but had to change this policy because, for example, it was not possible to provide a place to store the belongings of homeless people during their visit. Another problem was the complaints of some visitors about the smell of the homeless people. These situations give visitors new insights, sometimes more meaningful than those gained from museological objects. 
We sought to understand how the museums' contents affected the emancipation process. For processes related to boundary zones, we only considered the responses of MAR visitors, as the museums of Ouro Preto generated no boundary zones due to the style and spatial limitations of the buildings. A significant percentage of the respondents claimed to have changed their way of thinking about the world, and related this change to respect, a critical view of reality, and love. When we asked how their feeling of change involved the museum visit, we asked respondents to indicate whether the main reason was the content of the exhibitions, other reasons not related to the content (i.e., boundary zone), or both. The findings showed us that content of exhibitions most frequently provoked change in visitors' perceptions (44\%), while 18\% mentioned boundary zone, and 38\% indicated both factors. Thus, the museum content is a key factor, but not the only one. The presence of a boundary zone, both on its own and together with the content of the exhibitions, prompts transformation, thus indicating its role in the human emancipation process. The existence of the boundary zones and the evidence of the emancipatory potential of museums can, to some extent, reshape these organisations' reason for being.

Apart from the diversity of spaces, other aspects distinguish the MAR from the Ouro Preto museums in terms of how these spaces are used to expand opportunities for experimentation. For instance, the MAR management board promotes meetings with the local community that are not directly related to the exhibitions, for instance the Café com Vizinhos programme ('Breakfast with Neighbours'). Here, local residents in the neighbourhoods surrounding the museum are invited to participate in a conversation with its employees while having breakfast:

In the case of [the event called] Café com Vizinhos, the invitation goes like this: 'come over and bring someone you think should come too.' So, we never know in advance who's going to come, and there's always someone different. The neighbouring residents also invite other neighbours. So, there may be a guy who is developing a project or something. 'I've just moved here, I'm developing a film project.' And then the person next door says: 'I live here in Morro da Conceição, I came with my children-' So, this decision to include in the invitation the idea to invite whoever you think should come ends up in immense diversity. Besides, the museum's social media are absolutely organic. People start to enjoy and get involved with this space, so it's associated with the social networks, the newsletters, and the mailing. And with the Municipal Secretary of Culture, so that the information is disseminated. (R19)

In this space-time frame, within the physical structure of the museum, the population can propose themes and artists for the exhibitions. Residents may share sentiments about their problems and create proposals to be adopted in their lives. Sometimes the themes emerging from these encounters are forwarded by curators to guest artists, who use them to create exhibitions. These encounters, 
rather than works of art, can transform society - artists and audiences - through the museum.

\section{Conclusion}

This chapter has explored processes of estrangement and reconciliation between individuals and museums, analysed how these relationships are affected by the spatial dynamics of the museums in question, and examined where and how museums reinforce spatial appropriation. Although many residents feel estranged by museums, we also found opportunities for emancipation in how people experience museums. For instance, at the Rio Art Museum, the experiences occurring in the boundary zones and the direct participation of locals in the exhibitions, especially those about everyday life in Rio de Janeiro, engaged the city's inhabitants and fostered emancipatory reflections grounded in art.

Conversely, in Ouro Preto, even though the content of the historical museums is connected to the heritage that much of its population descend from, we observed that residents were even more detached. As possible solutions, we suggest two interrelated perspectives involving the experimental character of the museological space, and the link between the exhibitions and contradictions with the lives of Ouro Preto residents.

Our approach involves, above all, breaking through broader cultural barriers. It requires the recognition of various historically marginalised cultural manifestations that shape elements of the identity of Ouro Preto residents. These elements, in turn, relate to the very purpose of these museums. At this point, we suggest another emancipatory potential in the encounter between different cultural productions.

In the transformative role that we advocate for museums, they provide an education that perceives culture as the cornerstone of freedom and guides men and women through a continuous emancipatory process concerning their thoughts and actions. The effects of this education will be manifested at the level of democratic citizenry, since a democratic state requires real, conscious citizens who act in the world.

From this perspective, the opportunities for experimentation must be guided by a political experience based on a greater awareness of oneself, the world and its structures and the perception of oneself as an agent of transformation. As the study of the MAR revealed, it may not be paramount that the exhibition itself has an experimental form, for a significant part of the visitor's experience takes place in the so-called boundary zones.

Museums can also represent an opportunity to connect people to historical elements, because they unveil important contradictions of human development and foster the critical skills of individuals. Museums can become closer to the individuals and social groups who have remained historically alienated from these spaces. 


\section{Notes}

1 The Gold Cycle happened in the eighteenth and nineteenth centuries, when many expeditions from every region of the country, even from Europe, took the route to the hinterland of Minas Gerais to explore gold mines (Machado \& Figueirôa, 2001).

2 Inconfidência Mineira was a plot organised against the taxes on gold implemented by the Portuguese crown in the captaincy of Minas Gerais.

\section{Bibliography}

Alderoqui, S., \& Pedersoli, C. (2011). La educación en los museos: de los objetos a los visitantes. Paidós.

Boast, R. B. (2011). Neocolonial collaboration: Museum as contact zone revisited. Museum Anthropology, 54(1), 56-70.

Bourdieu, P. (2011). A distinção: crítica social do julgamento. Zouk. (Original work published in 1979.)

Bourdieu, P., \& Wacquant, L. (2012). Una invitación a la sociología reflexiva. Veintiuno Editores. (Original work published in 1992.)

Bruno, J. S. C. O. (2002). Museu da Arte Contemporânea de Niterói, RJ: Uma estratégia de promoção da imagem da cidade. Revista Brasileira de Estudos Urbanos e Regionais, 4(1), 91-105.

Canclini, N. G. (2009). Diversidade e Direitos na Interculturalidade Global. Revista Observatório Itaú Cultural, 8, 143-152.

Carlile, P. R., Nicolini, D., Langley, A., \& Tsoukas, H. (2013). How matter matters: Objects, artifacts, and materiality in organization studies. Oxford University Press.

Castro, D. C. (2013). Museus e educação sob inspiração de Paulo Freire. In C. Gurgel \& P. E. M. Martins (Eds.), Estado, organização e pensamento social brasileiro (pp. 191-216). Editora da UFF.

Castro, D. C. (2016). Alguém com quem contra: emancipação humana e organizações museais [PhD thesis, EBAPE-FGV]. EBAPE-FGV Research Repository. http://bibliotecadigital. fgv.br/dspace/bitstream/handle/10438/17054/Tese\%20Algu\%C3\%A9m\%20com $\% 20$ quem $\% 20$ Contar\%20Diana $\% 20$ Castro.pdf?sequence=1\&isAllowed=y

Dale, K. (2005). Building a social materiality: Spatialand embodied politics in organizational control. Organization, 12, 649-678.

Everett, J. (2002). Organizational research and the praxeology of Pierre Bourdieu. Organizational Research Methods, 5(1), 56-80.

Franklin, A., \& Papastergiadis, N. (2017). Engaging with the anti-museum? Visitors to the Museum of Old and New Art. Journal of Sociology, 53(3), 79-92.

Freire, P. (2001). Conscientização: teoria e prática da libertação: Uma introdução ao pensamento de Paulo Freire. Centauro.

Freire, P. (2007). Ação cultural para a liberdade e outros escritos. Paz e Terra.

Freire, P. (2011). Pedagogia do Oprimido. Paz e Terra.

Goulding, A. (2013). Older people learning through contemporary visual art: Engagement and barriers. International Journal of Art \& Design Education, 32(1), 18-32.

Hanquinet, L., \& Savage, M. (2012). Educative leisure and the art museum. Museum and Society, 10(1), 42-59.

ICOM. (2015). ICOM Portugal, definição de museu. https://icom-portugal.org/2015/03/ 19/definicao-museu/

Machado, I. F., \& Figueirôa, S. F. M. (2001). 500 years of mining in Brazil: A brief review. Resources Policy, 27(1), 9-24. 
Macleod, S. (Ed.). (2005). Reshaping museum space. Routledge.

Macleod, S., Hanks, L. H., \& Hale, J. (Eds.). (2012). Museum making: Narratives, architectures, exhibitions. Routledge.

Orlikowski, W. J. (2007). Sociomaterial practices: Exploring technology at work. Organization Studies, 28(9), 1435-1448.

Osorio, J. E. R. (2015). La des-contextualización en un museo del cuerpo en la 'calle de las guapas' de Manizales y la construcción de un corpus estético. Revista Lasallista de Investigación, 12(1), 177-191.

Pruulmann-Vengerfeldt, P., \& Aljas, A. (2011). Digital cultural heritage: Challenging museums, archives and users. Journal of Ethnology and Folkloristics, 3(1), 109-127.

Rectanus, M. W. (2002). Culture incorporated: Museums, artists, and corporate sponsorship. University of Minnesota Press.

Rectanus, M. W. (2006). Globalization: Incorporating the museum. In S. Macdonald (Ed.), A companion to museum studies (pp. 381-397). Blackwell.

Smith, T. (2009). What is contemporary art?. University of Chicago Press.

Sallaz, J. J., \& Zavisca, J. (2007). Bourdieu in American sociology, 1980-2004. Annual Review of Sociology, 33, 21-41.

Simon, N. (2010). The participatory museum. Museum 2.0.

Thiry-Cherques, H. (2006). Pierre Bourdieu: A teoria na prática. Revista de Administração Pública, 40(1), 27-55.

Urry, J. (1991). The tourist gaze: Leisure and travel in contemporary societies. SAGE.

Vergara, L. G. (2008). Utopias antropofágicas das raízes do Brasil. In M. S. Chagas et al. (Eds.), A democratização da memória: A função social dos museus ibero-americanos (pp. 245-266). Museu Histórico Nacional.

Vieira, E. F., \& Vieira, M. M. F. (2004). A dialética da pós-modernidade: A sociedade em transformação. Editora FGV.

Yin, R. K. (2009). Case study research: Design and methods. SAGE.

Zukin, S. (2010). The culture of cities. Blackwell. 